\title{
The Impact of Regulations on Public Supply Chain Performance: Case of Tanzania
}

\author{
Maganja Johanes Sospeter \\ Graduate School of International Management \\ International University of Japan, Niigata, Japan \\ Procurement and Logistics Management \\ Tanzania Revenue Authority, Dar es salaam, Tanzania
}

\author{
Wenkai Li \\ Graduate School of International Management \\ International University of Japan Niigata, Japan \\ lwk@iuj.ac.jp
}

\begin{abstract}
The supply chain in public sector in Tanzania has been characterized as being ineffective leading to the loss of taxpayers' money. Laws and regulations are key factors identified to pull back public supply chain performance's initiatives in public sectors. Reasons include i). Regulations are not realistic to the environment in which supply chain operates; ii). Laws and regulations are not flexible thus created a roadblock for practitioners to improve the efficiency or responsiveness in public supply chain. This paper conducted a survey interviewing 120 respondents with varying demographical characteristics and background in the field of supply chain management from both public and private sectors. The paper conducted data analyses using SPSS to study the impact of laws and regulations on public supply chain performance. The study showed that there is negative impact of laws and regulations (PPA2011) on effectiveness (cost) of a public supply chain. The study also found that PPA2011 has no significant impact on innovation and effectiveness of a public supply chain in Tanzania. This study suggests the Tanzania government amend sections of PPA2011 and regulations 2016 that seems to limit the performance of the supply chain in public sector. By doing so, a real benefit and essence of laws and regulations in the public supply chain will be harnessed.
\end{abstract}

Keywords- Operation Management, Supply Chain, Public Supply Chain, Regulations, Tanzania

\section{INTRODUCTION}

\section{A. Background of the study}

Taxpayer's money has been lost through ineffective public supply chain management (SCM) in Tanzania. Prominent factors that caused the loss of public fund were ethics, conflict of interest, inadequate monitoring and evaluation of the SCM, and lack of proper skills and capacity among government's officials. Laws and regulations are area identified to pull back the public supply chain performance initiative; this is because regulations are being not realistic to the environment the supply chain operates. Also laws and regulations are being not flexible thus created a roadblock for practitioners to meet an efficiency and responsiveness in public supply chain. Moreover, the rigidity of the laws has limited public supply chain practitioners to grab opportunity when arise, fearing to go against the laws. Also, there been conflict between the laws and the real situation of the environment in which the public supply chain operates and thus end up creating losses that are resulting from litigation imposed by private contractors. (The East African, Kenya; Sunday, April 6, 2013) Reported one of the real cases showing how public procurement Act 2011, was so rigid and led Tanzania to lose 65.8 Million USD through public procurement. The following are some few identified cases where public resources have been lost in SC activities.

The case where public fund lost:

Mamiro [1] discussed the case of Tanzania electricity company (Tanesco) and Ms. DOWANS which occurred in 2008. "Tanesco is a government-owned power generation Company under the Ministry of energy and natural resources, mandated to generate and supply electricity in the united republic of Tanzania. Tanesco is only Power Company that deals with electricity generation in Tanzania". Early in 2007, Tanzania experienced climatic change, and among of effects was causing droughts. Water falls where turbines for power generation resided dried-up. The country was in electric shortage, and the vulnerable consequences were to fall in the economy since the economic activities were not taking place because of power shortage. The government opted to lease power generation plant from Richmond of UK to solve the problem of power shortage. Richmond UK later changed ownership to Ms. DOWANS.

After leasing period, Tanesco was still in need of power plant for current as well for future use, and the cost of buying new plant was more than ten times while existing plant had similar condition like new one. After cost-benefit analysis conducted by Ms. Lehmeyer of Germany as a consultant, the deal was praised to be beneficial for the government. With the authorization from Minister for Energy, Tanesco's management signed the contract. After contract signing, the deal attracted the attention of political leaders especially from the opposition, who claimed that deal was contrary to public procurement Act 2004, Regulation 58(3) that prohibit the government's entities to procure used heavy plants and motor vehicles. Through parliament, Tanesco was ordered to rescind the contract. Ms. DOWANS filed a case against Tanesco to the court of International Chamber of Commerce. Ruling favored Ms.DOWANS on other side Tanesco was ordered to pay a sum of 65.8 Million USD as compensation for breach of contract. 


\section{Why PPA2011 rigidity is an issue?}

Tanesco's deal was done with due diligence regarding cost and benefits for the national; if could be successfully closed could have served a lot of public money. But before the PPA2004 this decision was null and void. One political leader opined.

"The Public Procurement Act should not be a road block to big energy infrastructure projects particularly those in which investors are involved and where the nation is in need."

The regulations have come up with laws that positively or negatively affected drivers of supply chain performance such as, facilities allocation and selection, inventory management, transportation, Information sharing, product pricing, and sourcing. Different sections of Public procurement Act (PPA) and regulations will be explored in details to find out how positive or negative can impact on the SC performance. Previous studies have been conducted to assess different facets of supply chain regarding effectiveness, responsiveness, and efficiency, but given little insight on the consequences of the government regulations on the supply chain performance.

\section{B. Evolution of the public procurement in Tanzania}

There are a lot of changes of public procurement framework, from since we got independence as compared to nowadays [2]. There have been changes in the political, economic and commercial environment in Tanzania, particularly in recent years when the resurgence of commercial life and the availability of foreign exchange to pay for imports have resulted in goods being freely available from a variety of sources. In this regards the public entities started to change their SC decision to suit the current situation, For instance, most of the institutions they started to change policy on inventory, implementing efficiency and effective inventory techniques like JIT.

The Constitution of the United Republic of Tanzania contains provisions relative to the finances of the Government. Under the old public procurement system, the legal environment was based mainly on the Exchequer and Audit Ordinance, CAP 439 of 1961, the various laws establishing the specific public authorities.

On 30th December 2011 new public procurement legislation was passed by the Parliament and was subsequently signed into law (The Public Procurement Act No. 7 of 2011) by the President. The law passed amended some parts that the government though needs improvement or has shown some weakness in its implementations.

World Bank and other donors who influence our countries have been influencing the reform of procurement in public sector to ensure that their funds are being utilized properly.

For example, in 2002 the World Bank engaged a Consultant to carry out a country procurement assessment. The Country Procurement Assessment Report (CPAR 2003) came up with some recommendations which related to the legislative framework, the procurement system, and processes, capacity to conduct procurement and effects of corruption in procurement process. The CPAR 2003 report recommended some issues to be incorporated in the country procurement regulations, and the government through the parliament passed the law to accommodate that recommendations.

The remarkable reforms in the public procurement were enactment of the new Public Procurement Act, (PPA 2004) which repealed the PPA 2001. The PPA 2004 became operational in May 2005; The PPA 2004 fully decentralized the procurement functions to procuring entities and established the procurement oversight body, The Public Procurement Regulatory Authority (PPRA).Following this reform, the Government has mandated the Public Procurement Appeals Authority (PPAA) with the function of resolving complaints and disputes arising from the procurement process.

Although the act seems to have some bottleneck has it does not to cover about the performance management of the public supply chain officials, also does not cover the contract management after the tender is awarded, that is during the implementation stage. This indicates need for more reforms.

\section{Procurement Regulations inside the government}

There are two types of the regulations that are done by a government. The first type is the outside government regulation; this means government bodies regulate private entities. The second type is the regulation of the government; government bodies regulate other government bodies. This research focused on the second type of regulation, the regulation of the government.

Regulations inside the government are further classified into three categories that are; the regulator where has high degree of authority over regulated bodies and set the standard for them. Another type of regulation is the one who monitors the performance and uses persuasion or direction of regulated body to change their behavior. The last type of the regulation within the government is the separation of the regulator and regulated within the organization. Regulation is distinct from internal management within an organization [3].

Regulations are the obligations of one organization over the other organization or person regarding the authorizations that are given to that body [4]. The regulator is responsible for reward and sanctions over regulated body depending on the level of performance to comply with the regulations. In Tanzania, the main regulators of the supply chain related functions in the public organizations, incudes not limited to:

- Ministry of Finance (MoF)

- Public Procurement Regulatory Authority, PPRA

- The Public Procurement Appeal Authority (PPAA)

- National Audit Office, being the major regulator, while others being

- Attorney General office,

- Parliamentary Commissioner for Administration

- Prevention and combating of corruption bureau.

In the following section, the researcher described the regulators regarding the power invest to them and the section 
of the laws that has invested them with such power to oversee procurement activities in the united republic of Tanzania.

\section{1) Ministry of Finance}

(PPA2011) has pinpointed the power and responsibility of MoF. "The Ministry of Finance is one of the major actors in the procurement system with the responsibility of ensuring that funds are available and disbursed to the procuring entities according to the budget and plans for the government institutions to implement their functions in the respective financial years.

\section{2) The Public Procurement Regulatory Authority (PPRA)}

(PPA2011), "The PPRA has been established under Section 5 of PPA in 2004 under the Ministry of Finance as an oversight body in the procurement functions in the country as well as regulating and monitoring procurement activities undertaken by the PEs. The main objective of monitoring procurement activities is to ensure that the funds disbursed by the government for procurement of goods, non-consultancy service, disposal of public assets by tender and consultancy services are utilized by procedures laid down in the Act and its regulations. The PPRA has the responsibility of ensuring that there is application of fair, competitive, transparent, and nondiscriminatory and value for money procurement standards and practices in public procurement system".

\section{3) The Public Procurement Appeal Authority (PPAA)}

The Public Procurement Appeals Authority (PPAA) was established under Section 77 of the PPA in 2004 to provide for an independent mechanism to deal with the handling of complaints and appeals arising in the public procurement process. The PPAA is also providing clarification on disputes among parties as well as providing advice to the Public Procurement Regulatory Authority on areas requiring improvement within the public procurement process.

\section{4) National Audit Office (NAO)}

Public Finance Act (PFA) and Local Government Finance have perpetrated power to NAO. "The National Audit Office of the United Republic of Tanzania (NAO) is established under Article 143 of the Constitution of the United Republic of Tanzania. The statutory duties and responsibilities of the Controller and Auditor General (CAG) are provided for in the Public Finance Act (PFA) No. 6 of 2001 and the Local Government Finance Act No.9 of 1982. The NAO has responsibilities of undertaking external financial and performance audit of all government entities, public authorities and other bodies at least once a year. Also, NAO is required under section 33 of the PFA 2001 to carry out Performance Audit and report to the Parliament on the economy, efficiency and effectiveness in the use of public money and other resources. The performance audit performed by NAO also covers expenditure of funds being used for procurement of goods and services by the government entities.

\section{5) Prevention and Combating of Corruption Bureau} $(P C C B)$

The Prevention of Corruption Act No. 3 of 1971 has been repealed by the government and enacted the Prevention and Combating of Corruption Act, 2007 which provides the overall legal framework for prevention and combating corruptions in
Tanzania. The enacted Act has provision of corrupt transactions in contracts (Section 16) and corrupt transactions in procurement (Section 17) which state the penalties for person convicted of such offenses. The Act also provides extensive protection to informers (whistleblowers) Section (51) as well as protection of witnesses, experts and victims (Section 52).

\section{6) Supply Chain Performance}

Performance varies from activity to activity and from one type of organization to another. Supply chain performance lies in the ability of the organization to respond to customer requirements, innovatively while maintaining speedy delivery at lowest cost.

Meindl et al, [5] argued that supply chain performance can be measured by the ability to create value for customers. Achieving strategic fit is necessary for value creation. Strategic fit can be achieved through a well-balanced functional strategies and SC drivers. To achieve the strategic fit, require understanding of the supply chain capabilities, through well pre-identified goals to be achieved.

Overall performance can be demonstrated by the ability of an SC to spot the ideal position on the cost-responsiveness efficiency frontier. An organization might choose to be more responsive that being cost efficiency, the opposite is true; depending on the products and services provided by the SC. To achieve the public supply chain performance, the implementation of the strategies should be in line with the policies and procedures that are governing the public supply chain. Results of missing connection nodes between the supply chain performance drivers of public supply chain and laws and its regulation is a complex network of conflicting activities and events and eventually inefficiency in public supply chain [33].

\section{Statement of the problem}

The regulations have come up with laws that adversely affect the drivers of supply chain performance like, facilities allocation and selection, inventory management, transportation, Information sharing, product pricing, and sourcing.

Also, apart from the key drivers of the supply chain performance, there is other concern like the process itself in the execution of the supply chain activities in the public organizations. Policies and regulations are often confusing and cumbersome. Suppliers have to fill out numerous forms, often many times. This costs time and money and is a particular problem for small businesses with little or no administrative capacity or support. It is government policy to support the growth of small businesses and the jobs they create. Procedures are also difficult for officials to interpret and implement.

Moreover, at individual level, public servants rely on the PPA rules and cannot think for themselves whereas private sector practitioners think for themselves based on commercial knowledge. Most public sector individuals lack competence, are afraid to speak up, afraid to challenge the status quo, and without the PPA guideline by their side, they panic through fear of job loss [6] 
The author believes that public fund has been lost through ineffective SCM. Some of the practices that caused the loss of public fund were ethics and conflict of interest, inadequate monitoring and evaluation of the SCM, and lack of proper skills and capacity. To ensure that the public fund is being utilized effectively different ways to overcome the problem were suggested, and among the solution is to put down different regulation and laws. Author's doubt lies on the whether the regulation has been there to create value in SC or create operational bottleneck and hence affect performance.

\section{E. Research Objectives}

\section{1) General objective}

The main objective of this thesis is to find the relationship between the law and regulation against performance in the public originations' supply chain. The study will come up with recommendations on how to improve performance in the public supply chain.

\section{2) Specific objectives}

i. To examine the laws and regulations those are going against the key performance indicators of a successful supply chain, regarding innovation, responsiveness, and efficiencies.

ii. To establish the relationship regarding performance outcomes between regulated public SC and unregulated private supply chain management.

iii. To assess other factors that contributed to inefficiency in the supply chain that has no connectivity with the laws and regulations.

\section{F. Research Questions}

a. Does public procurement laws and regulation (PPA2011) has impact on public supply chain performance regarding innovation?

b. Does PPA2011 have impact on public supply chain performance regarding responsiveness?

c. Does PPA2011 have impact on public supply chain performance regarding efficiency?

\section{G. Research Hypotheses}

\section{First Hypothesis}

Ho= PPA2011 has no impact on public supply chain performance regarding innovation

H1= PPA2011 has impact on public supply chain performance in terms of innovation

\section{Second Hypothesis}

Ho $=$ PPA2011 has no impact on public supply chain performance in terms of responsiveness

H1 = PPA2011 has impact on public supply chain performance in terms of responsiveness

\section{Third Hypothesis}

Ho= PPA2011 has no impact on public supply chain performance in terms of efficiency

H1 = PPA2011 has impact on public supply chain performance in terms of efficiency

\section{H. Significance of the Study}

i. The findings of the study will specifically help the policy makers to revisit regulations and where appropriate to check the possibility of correcting current weaknesses.

ii. The study will also help policy makers to formulate ways on how to improve the service delivery in the economy as well as to promote value for money in public supply chain.

iii. The study will also act as a basis for further researches in the field of Public procurement in Tanzania.

\section{Scope of the Study}

The study was carried in Tanzania included both public and private sectors; selection was on random way where respondents from different institutions to represent all supply chain specialists in Tanzania were selected. The main objective was to survey on the public sector but to come up with good comparisons with private entities; the study has to include respondents from the private sector to give the overview of the supply chain operations in their respective organizations. Moreover, apart from using respondents, some secondary data and earlier research on public sectors supply chain was revisited.

\section{J. Organization of the Study}

In Section One, the study covered the Introduction, Background information, Statement of the problem, Research Objectives, Research Questions and Significance of the study.

In Section Two, the study focused on the literature from books, journal, previously research papers and different countries reports on the regulations and its influence on the public procurement, literature covered empirical review, theoretical review, and conceptual framework study.

Section Three, the study will cover the Research Methodology which will comprise of Research Paradigms (Philosophy), Research Design (Strategy), Types of Measurement to be used, Data collection methods and approach, Types of data, Sampling techniques, Management and analysis of the data.

In Section four, the study covered analysis of data, presentation of statistical data and discussion of the results.

Section five concluded the study and recommended the study findings and observation to government as well as to future researchers in the area of procurement and supply chain management. 


\section{LITERATURE REVIEW}

\section{A. Introduction}

In this Section, the public supply chain will be analyzed in depth, and different theories will be gathered to support the thesis findings. To achieve thesis objectives different kinds of literature from books, journal, previously research papers and different countries reports on the regulations and its influence on the public procurement will be consulted to come up with the good context towards creating good analytical framework. Literature will cover empirical review, theoretical review, and conceptual framework study.

\section{B. Empirical Review}

This part will try to review some studies that are being covered by other researchers in the area of public procurement, regulations and the performance of the supply chain in general. The literature reviewed will try to give deep insight on what researchers explored during their studies, and will give this thesis a solid foundation to understand the phenomenon in more details. The concepts that will be cover include but not limited to supply chain management, regulated supply chain and private, unregulated supply chain.

\section{1) Overview of Supply Chain Management}

A supply chain consists of all parties involved, directly or indirectly in fulfilling the customer requests [6]. The supply chain includes not only the manufacturers and the suppliers, but also all parties that assist in one way or another in smoothly conveying the products or services from the point of production to the point of consumption, including even the customers themselves.

Supply chain management is the act of overseeing and managing a supply chain to ensure it is operating as efficiently as possible, thus ensuring that the right product is produced and distributed at right location in right quantity at right price, thus minimizing the total system cost while maintaining the ethics of the business practices [7]. In this regards, the SCM refers to the upstream and downstream linkage of the different activities and functions that facilitate the movement of goods and service from the point of production to the point of consumption with the related information flow

Muriel et al [8] defined supply chain as "Supply chain management is a set of approaches utilized to efficiently integrate suppliers, manufacturers, warehouses, and stores, so that merchandise is produced and distributed at the right quantities, to the right locations, and at the right time, in order to minimize system-wide costs while satisfying service level requirements".

\section{2) Difference between Public and private sector Supply} Chain.

One of the main distinguishing factors between public and private supply chain in Tanzania is the way how procurement is conducted.

Tanzania Procurement Journal (vol.1 no.1 2008), defined 'Public Procurement' as the purchasing, hiring or obtaining by any other contractual means of goods, construction works and
Table I. Public versus private sector supply

\begin{tabular}{|c|c|c|}
\hline Features & Private sector SCM & Public Sector SCM \\
\hline Goal & $\begin{array}{l}\text { Profit making from } \\
\text { customers }\end{array}$ & $\begin{array}{l}\text { Quality services } \\
\text { delivered to the society }\end{array}$ \\
\hline View of SCM & $\begin{array}{l}\text { Procurement is viewed as } \\
\text { an element of SCM }\end{array}$ & $\begin{array}{l}\text { SCM is viewed as a tool } \\
\text { for procurement }\end{array}$ \\
\hline Sources of revenue & $\begin{array}{l}\text { Sales of goods and } \\
\text { services }\end{array}$ & Taxes and fees \\
\hline Governance & $\begin{array}{l}\text { Guided by the body of } \\
\text { directors and business } \\
\text { plans }\end{array}$ & $\begin{array}{l}\text { Legislative bodies, laws, } \\
\text { and regulations }\end{array}$ \\
\hline Skills & Have highly skills actors & Have less skilled actors \\
\hline Receptiveness & $\begin{array}{l}\text { Emphasis on the } \\
\text { innovation } \\
\text { entrepreneurship }\end{array}$ & $\begin{array}{l}\text { Emphasis on the } \\
\text { accountability } \\
\text { transparency }\end{array}$ \\
\hline $\begin{array}{l}\text { Organizational } \\
\text { Structure }\end{array}$ & $\begin{array}{l}\text { Firms of many sizes with } \\
\text { room for new } \\
\text { entrants(less complex) }\end{array}$ & $\begin{array}{l}\text { Highly complex system } \\
\text { of organizations with } \\
\text { various tasks }\end{array}$ \\
\hline Competences & Very high & Low \\
\hline Confidentiality & Very high & Low \\
\hline $\begin{array}{l}\text { Degree } \\
\text { collaboration }\end{array}$ & Very high & Low \\
\hline $\begin{array}{ll}\text { Degree } & \text { of } \\
\text { integration } & \end{array}$ & Very high & Low \\
\hline Strategic Partnership & High level & Low \\
\hline $\begin{array}{ll}\text { Degree } & \text { of } \\
\text { Implementation } & \\
\end{array}$ & High & Low \\
\hline $\begin{array}{l}\text { Technological } \\
\text { application }\end{array}$ & High application & Low application \\
\hline
\end{tabular}

services by the public sector. Public procurement refers to the purchase by governments and state-owned enterprises of goods, services and works. The public procurement process is the sequence of activities starting with the assessment of needs through awards to contract management and final payment.

While private organizations are profit-oriented and mainly focus on increasing returns for company owners or shareholders. Their procurement activities are confidential; they operate in a competitive business environment, where sharing trading intelligence with competitors isn't advisable.

Ambe et al [9] defined public sector SCM as a concept that offers a reference framework for the composition of public sector supply chains and multilevel networks. They added that the public supply chain is also relating on the way public institutions they relate even to the private suppliers in the ultimate goal that the goods can be moved from the point of the production to the point of consumption.

Migiro [10] referring to OGC (Office of Government Commerce) report, shows the focus of supply chain (SC) can differ from government sector-to-sector. In the health sector, the focus may be more on logistics and the effective movement of goods and services in and out of hospitals whereas SC in the education sector may focus on streamlining the chain through which teaching materials are delivered to students.

Huang [11] noted that, while private sector procurement is more open to entrepreneurship and innovation; public procurement is based on legislation, policy and process. Public sector procurement serves a broader range of stakeholders, places greater emphasis on accountability and transparency, 
and allows little or no flexibility for negotiating with bidders/responders to a request for proposal (RFP). McGuinness et al [12] asserted that "the skill set of the public sector purchasing manager is geared more toward supervising the procurement process and preparing reports than negotiating the best deal." However, they suggest flexibility rather than formality is the key to improving public procurement performance.

Furthermore, difference between public and private supply chain is as shown in adopted table I above by the author from the literature.

\section{3) The Public Procurement Act No 3 of 2011}

The Public Procurement Act No 3 of 2011 is the main act that affects the procurement process in public SC. We describe the details in this section. On 30th December 2011, new public procurement legislation was passed by the Parliament and was subsequently signed into law (The Public Procurement Act No. 7 of 2011) by the President.

The Act provides a comprehensive coverage of all regulatory aspects critical to public procurement. The new Act:- (a) applies to all procurement undertaken by public institutions except for financially independent parastatal organizations and for defense procurement, (b) makes deference to the international obligation of Tanzania at the intergovernmental and international levels, (c) does not cover contract performance or implementation phase, (d) takes into account certain differences between the procurement of goods, works and selection and employment of consultants and (e)establishes several tender boards with the responsibility for procurement, review of tender documents and contract awards in accordance with pre-determined thresholds. The Act also provides for the establishment of the Public Procurement Appeals Authority to settle procurement disputes before judicial review process.

Furthermore, the continued evolution of act in Tanzania aimed to the improvement of procurement conducts to the public procurement entities. The Public Procurement Act, 2004 - (Act No. 21/04) and its regulations of 2005 established to repeal the Public Procurement Act, 2001 with a view to make better provisions for the regulation of Public Procurement in the Government of the United Republic and to provide for other related matters. The PPA of 2004 was replaced by PPA of 2011 and regulation of 2013 with effect from Dec 2013. The PPA is applicable to all procurement financed by public funds; however Local Government procurement is regulated by the Local Government Finance Act 1982 as amended from time to time. The act sets out a public procurement system which aims to ensure the procurement is conducted in a fair and transparent, accountable and in a competitive manner.

Also aimed to contribute towards the creation of sound economic climate in Tanzania, and increase participation by the Tanzania private sector. Also the public procurement act aimed at monitoring compliance of public procuring entities, as well strengthening collaboration and coordination of different sectors of government so that value for money and compliance to laws in the procurement process can be achieved.

\section{Theoretical backgrounds of the study}

Theory being statement and principle that are formulated to explain, predict and understand the phenomenon, under this section will be used to give support to criticize and support the existing knowledge in the regulated supply chain within a given limit of bound assumptions. Better seeking the theoretical arguments will help me to support theory of my study. The main possible useful of the study will be explaining why certain problem under research exist. The main outcome of this thesis will be coming up with the answer to whether the problems real exist or not.

Under this study, following theory will be analyzed as connected to supply chain management in public sectors such as "Hegelian dialectic theory," "Principal-Agent theory" and "Innovation Theory."

\section{1) Hegelian Dialectic theory}

The dialectical theory begins with the Hegelian assumption that "organizational entity exists in a diverse world of colliding events, forces, or contradictory values that compete with each other for supremacy and control" [13]. This diversity may be found within an organizational entity, and sometimes may also be external to the organizational entity. Author used dialectical theory to explain the change in organizations as occurring when the opposing values, forces or events gain sufficient power to confront and engage the status quo. These opposing forces are termed thesis and antithesis, the thesis being the status quo or the ruling way of "doing things". These may be in the form of workaround, e.g. by specifying requirements which favor other goals than just costs. As previously shown, findings from two case studies of procurement in local government identify different tensions in the procurement process. However, dialectics serves a limited role as the analytical lens in identifying conflicts. To understand why these conflicts arise and how different persons or subgroups involved influence the process, other theoretical lenses are needed, and principal- agency ties well with dialectics.

\section{2) Principal-Agent Theory}

Guston [14] concluded that there are many literatures that discussed the existence of the delegation problem that is commonly explained by the theoretical concept known as the "principal-agent relationship." Agency theory emphasis the relationship that is existing between one person who is known as the principal, contract another person who is known as the agent to perform some obligation on behalf of the principal, by being entrusted with full authority to take decisions for the interest of the principal. In exercising the mandate, the agent should act in the interests of both parties [15].

Principal-agent relationship is destroyed by the agent since the agent possesses information, skills, and ability needed than the principal. In Tanzania procurement system, the principal is government, and the agents are the government bodies that are delegated to perform procurement activities on behalf of all people in Tanzania. Among of the government's agents is Tanzania Revenue Authority, whose has mandated to carry procurement activities, to support internal activities that stimulate the tax collection in the country[16]. 
Furthermore purchasing officials (agents) are rational, and have high desire to maximize the outcomes of the service to their principal. On contrary, other theories assume that agents have conflicts of interest, in the sense that they strive to maximize their interest beyond the principal interest or common interest under principal-agent contract. From this ambiguity, Fama et al [17] conceded that principal and agent do not share same information; further, this situation creates asymmetrical information sharing. This theory concludes that there are always the regulators, but they do not have the information needed to effectively regulate and appraise the performance of purchasing officials (or agents).

\section{3) Theory of Innovation}

Innovation is best described as the foundation where new ideas are built by individuals, teams and the organization. To achieve innovation takes human being adaptions to the ideas. To harness the fruits of innovation, individuals, teams, and organizations need a self-regulated environment and manage the new idea demand of innovation towards new idea generation and innovation [18].

Benner et al [19] asserted that a generation of new idea and implementation of the same always create the dilemma and conflicts as they are to perform both at one time. The main conflicts come to the facts that implementation of new idea is associated with cost impact, also the other challenges is the implementation of innovative ideas that will be going against existing procedures which are governed by the laws, eventually innovation becomes impossible and thus limiting the attainment of value for money and attainment of the best practices [20]. Also, the regulations have sacrificed greater opportunity for innovation, which is the catalyst for efficient SCM, better quality, faster delivery and reduce whole life costs.

\section{Conceptual Framework of the study}

To come up with the visible cause and effects analysis, the study will employ the supply chain decision-Making framework in order to show how supply chain performance can be measured and how the regulations in Tanzania public organization affect these key performance indicators. In order organization or company to perform well in supply chain, requires the balance between responsiveness and efficiency that best support the organization competitive strategy. Supply chain Performance in terms of efficiency and responsiveness is based on the interaction between the logistical and the cross function-drivers of the supply chain performance [21]

\section{1) Inventory}

Inventory includes all goods that are in forms of raw materials, work in progress and finished goods that are still on the supplier premises or ownership. Inventory decision is a very important, because excess of what is needed to satisfy customer demand, increases inventory holding costs, and too little inventory means the organization cannot meet customer requirements and increases ordering cost such as frequently ordering

\section{Supply Chain Decision-Making Framework}

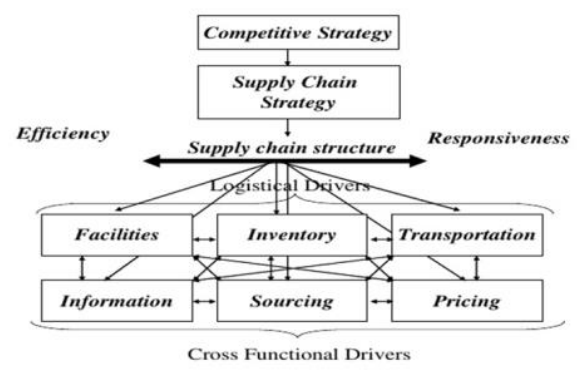

Fig. 1. Drivers for supply chain Efficiency and Responsiveness

Source: Supply Chain Management, Strategy, Planning, and Operation (Sunil Chopra 6ed)

\section{2) Facilities}

Facilities are the actual location in the supply chain network where the product is stored, assembled, or fabricated. The two major facilities are the production site and the storage site. Decisions regarding the role, location, capacity and flexibilities of the facilities have a significant impact on the supply chain's performance. Facilities decisions give the optimal location of the facility in reflation the parties to be saved by the facilities, thus reducing the distance automatically reduce the SC cost while increasing the SC performance.

\section{3) Transportation}

Transportation plays a role of moving materials from one place to another in the supply chain. Transportation has higher influence in the supply chain interns of both responsiveness and efficiencies. The choices of Transportation also affect facilities and inventory policy in the supply chain. Transportation decision should be thought considering the effect of the quick responses and inventory carrying cost. Increase in a number of deliveries usually increases transportation cost while setoff with the cost that could be used to keep inventories in the storage. Transportation decisions should be based on its role in the competitive strategy, that is to minimize cost of supply chain, or to create more responsive supply chain while keeping less consideration on cost increases.

\section{4) Sourcing}

Sourcing determines who will perform certain activity in the supply chain. Efficiency and effectiveness can be achieved by the organization to change the sourcing strategies on what to perform inside and what to be outsourced, and deciding who to perform what activities. Both in private and public entities, sourcing is done through procurement.

Procurement in the public sector is more rigid and strives to comply with the rules and regulations. Also, public sectors limit innovation and application of the negotiation strategies that can help to come up with a good deal in all process of procuring due to the limitation of the decision making. While in the private supply chain, employees are free to take 
competitive decision that will results to higher value deal thus a maximization of profitability.

\section{5) Information}

Information plays a crucial role in the supply chain, thus affecting every driver in the supply chain. Information facilitates achievement of responsiveness in case when a quality information is disseminated promptly, also facilitate efficiency is the information can be used to decide the capacity utilizations.

Wong et al [22] argues that, increase in information sharing in the supply chain results in the system total cost reduction, higher rate of order fulfillment, thus reducing the demand uncertainty and total increase in the system profitability. As the players in the supply chain share information, as the responsiveness and effectiveness are achieved.

Choice of the information be shared depend on the type of the supply chain process design. The information that is required in the push design are always MRP, that to make easier to plan for production, planning for raw materials acquisition and arrange for product delivery. Pull system usually require actual demand information that is more accurately, and transfer the products to meet the actual demands.

\section{6) Pricing}

Price is the process by which supplier decide how much to charge the customer for goods and services. Price most of time act like a lever that links the demand and supply. The pricing decisions can highly affect the responsiveness and efficiency of supply chain [23]. Both public and private engage in the procurement of similar products that are priced either at a listed price or using competitive tendering. He further found that public and private pricing decisions differ, for instance in USA, the public entities are mandated to use a fixed price catalog. The pricing decisions can vary depending on the item being procured, and these variations range from fixed-price contract, bidding, and negotiation.

\section{RESEARCH METHODOLOGY}

\section{A. Introduction}

This Section will introduce variables (conceptual framework) lead to a conclude the regulation impact on the supply chain performance in the public sector supply chain. Furthermore, this Section will present the material and methods that were used to collect and analyze data.

\section{B. Variables (Conceptual framework)}

This conceptual framework of the study is adopted from the book; Supply Chain Management, Strategy, Planning and Operation [24].The framework was restructured in Figure 2 below in order to bring clear visibility of the depend and independent variables.

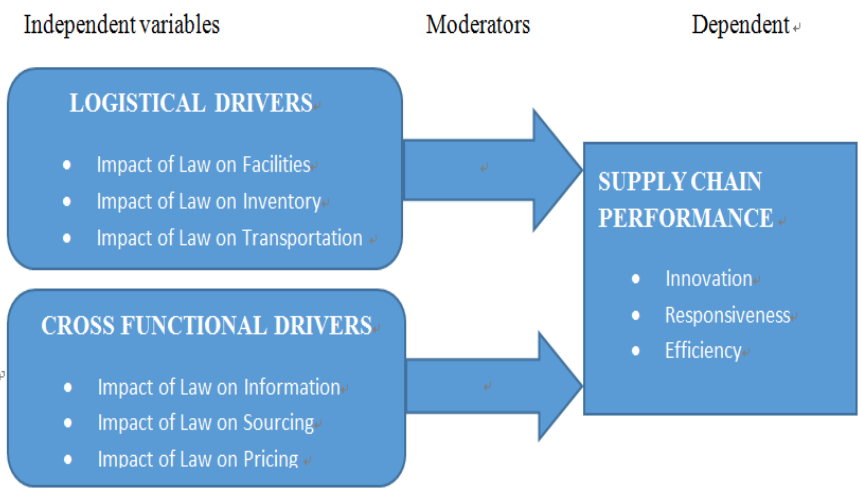

Fig. 2. Conceptual framework, Public SCM drivers and Performance Matrix

\section{Study Design}

The design of the study was built on the exploratory and descriptive framework, trying to find information of the population by using some variables to measure certain status of the topic under study [25]. The information that will be collected under this study will be used to explain the impacts regulations can impart on the performance of the supply chain in the public sectors.

Further author suggested that a survey is best way to collect data that can be used to explain the status of the problem under study. Before data collection, systematic way of identifying the targeted population was though, the questionnaire was prepared to suit the required information with relevant to understanding capacity of the sample to be studied.

\section{Targeted population}

Under this study the targeted population was both private and public supply chain specialist and non-supply chain specialist that are in the managerial level in the organizations, as they have influence on decision making pertaining supply chain performance.

Survey was conducted online by sharing hyperlink and requesting the senior level employees to share link to junior level employees with significant knowledge in the supply chain operations. The main factor to identify the right respondents was ability to understand the procurement laws and regulations and the ways how do operate. This approach helped author to have higher percentage of the responses, but with few outliers from the aspects which I have considered to be important, that is knowledge of the public procurement act.

\section{E. Sampling}

This will be the process of selecting number of individuals or objects from the population such that the selected group contains some characteristics found in the entire group. The technique used was probability or non-probability. The researcher used non-probability technique, which based on his/ her judgment. 


\section{F. Data Collection}

Data collection was through online system using Google forms, after filling the questionnaire parts, respondents were supposed to submit under submit button in the Google form and the responses were collected and recorded instantly.

The method was very effective as it gave respondents enough time and convenience, and allowed them respond to questionnaire through their mobile phone of electrical device and also limits the possibility of the questionnaires to be returned unfilled since the system will not allow partial filled questionnaire to be submitted as long as the system is configured well.

\section{G. Data analysis}

For data analysis the researcher used qualitative data analysis techniques assisted by using SPSS software. Finally required information tables, percentages and counts was prepared and presented.

\section{DATA ANALYSES AND DISCUSSION}

\section{A. Introduction}

This Section covered data analysis, presentation and discussion of the general information provided by respondents, also studied the respondent' demographics. It also responds to research questions where each of the questions is answered by the analysis of the obtained data and presented through tables. The impact of the regulation on the supply chain performance was analyzed and the results are reported on the means tables with their respective standard deviations and correlations to key variables.

Regulation and compliance, in essence, is to make sure that government officials are performing their duties by following guidelines put in place, and those guidelines are structured in the way that will create high performance in the public supply chain activities. Procurement Performance in the public supply chain means achieving a right balance between effectiveness and responsiveness, supported by employees' ability to innovate the ways that can improve performance in the public supply chain while attending to the public social needs and wants.

Public procurement is being fueled by the political fight for the public confidence that is built on the pillars of transparency, equity and fair dealings [26]. Procurement alike to other government function is regarded as the processing of the administrative process and implementation of the policy through highly regulated system.

A highly regulated procurement system is designed to minimize the risk that might occur due to the discretion of the practitioners in a highly risk decision making. Also a highly regulated procurement system is prevailing in the jurisdictions for the government officials who lack skills in the executions of their mandate, and also where government strives to ensure transparency, prevent or overcome corruption practices. Compliance means the minimization of the decisions making risk in the public procurement process by imposing highly regulated processes.Assessment of the management performance is based on the level of compliance with the prescribed processes.

The penalty of the regulations as come up with the lack of flexibility in the management of the agency needs effectiveness and efficiency. Also, regulated processes are procedurally costly, and also bring challenges in the management of the simple procurement since it slowly adapting to the changes that should be linked to the complexity and ever changing sophisticated supply chain. The other consequences are the erosion of the skills and personal developmental in the decisions making, therefore undermining their professionalisms. This will further increase the cost of implementation of the system as well as the frequency of training for the procurement staff that will be required due to the over changing of the regulations due to the changing of the supply chain as well as technology.

\section{B. Data collection}

In this study, the researcher sent questionnaire to 150 respondents in Tanzania through a Google form, and responses collected were $80 \%(n=120)$ of the sampled population. This response rate is higher than average of $30-40 \%$ response rate for internal survey suggested in different literatures and $24 \%$ response rate using email or similar method for data collection.

Groves [27], claimed to get accurate measurements with less than $20 \%$ response rate, using email to conduct survey. Out of total respondents who were sampled for this research, only $20 \% \quad(n=30)$ did not respond on time; Table II below illustrates this information.

Table II. Response Rate

\begin{tabular}{|c|c|c|}
\hline & Frequency & Percentage \\
\hline Collected responses & 120 & 80 \\
\hline Uncollected responses & 30 & 20 \\
\hline Total & 150 & 100 \\
\hline
\end{tabular}

\section{Demographic Data}

\section{1) Gender of the respondents}

The questionnaire was distributed to high diversity of the respondents disregarded to their gender by using Google online questionnaire method. After the given time frame for responding to the survey, number of respondents categorized by their gender as shown in the table III male were $66.7 \%(n=79)$ and female were $33.3 \%(n=41)$.

Table III. Gender Responses

\begin{tabular}{|c|c|c|c|c|}
\hline & & \multicolumn{2}{|c|}{ Sector } & \multirow{2}{*}{ Total } \\
\hline & & Private Entity & Public Entity & \\
\hline \multirow{2}{*}{ Gender } & Female & 21 & 20 & 41 \\
\hline & Male & 28 & 51 & 79 \\
\hline \multicolumn{2}{|c|}{ Total } & 49 & 71 & 120 \\
\hline
\end{tabular}


Table IV. Gender Responses Rates

\begin{tabular}{|c|c|c|c|c|}
\hline \multicolumn{2}{|c|}{} & \multicolumn{2}{|c|}{ Sector } & \multirow{2}{*}{ Total } \\
\cline { 3 - 4 } \multicolumn{2}{|c|}{ Gender } & Private Entity & Public Entity & \\
\hline & Female & 21 & 20 & 41 \\
\cline { 2 - 4 } & Male & 28 & 51 & 79 \\
\hline \multicolumn{2}{|c|}{ Total } & 49 & 71 & 120 \\
\hline
\end{tabular}

2) Sector of respondents

The questionnaire wanted to capture the respondent's working sector. The distribution of respondents is $59.2 \%($ $\mathrm{n}=71)$ are in public sector, $40.8 \%(\mathrm{n}=49)$ are in private sector; however $9.2 \%(n=11)$, they don't belong in these two large groups and a likely to be self-unemployed were included in the private sector, making $\mathrm{n}=49$ for easy analysis.

Table V. Sector of Respondents

\begin{tabular}{|c|l|l|l|l|l|}
\hline \multicolumn{2}{|c|}{} & Frequency & Percent & Valid Percent & Cf \\
\hline \multirow{3}{*}{ Valid } & Private Entity & 49 & 40.8 & 40.8 & 40.8 \\
\cline { 2 - 6 } & Public Entity & 71 & 59.2 & 59.2 & 100.0 \\
\cline { 2 - 6 } & Total & 120 & 100.0 & 100.0 & \\
\hline
\end{tabular}

\section{3) Respondent's rank in the organization}

From the data collected, shows that $35.8 \%(n=43)$ of total respondents are in the operational level, $40 \%(n=48)$ are in the middle level, $12.5 \%(n=15)$ presents head of departments and senior level, and $11.7 \%(n=14)$ presents other category of rank. Table VI below shows the rank distribution of the respondents. Respondent's rank in the organization

Table VI. Respondent's Rank in The Organization

\begin{tabular}{|c|c|l|l|l|}
\hline \multicolumn{2}{|c|}{} & \multicolumn{2}{c|}{ sector } & \multirow{2}{*}{ Total } \\
\cline { 2 - 5 } & Private Entity & Public Entity & \\
\hline \multirow{4}{*}{ Position } & Head of department. & 6 & 8 & 14 \\
\cline { 2 - 5 } & Middle level. & 15 & 33 & 48 \\
\cline { 2 - 5 } & Operational level. & 14 & 30 & 44 \\
\cline { 2 - 5 } Others. & 14 & 0 & 14 \\
\hline \multirow{2}{*}{ Total } & \multicolumn{2}{|c|}{$\mathbf{4 9}$} & $\mathbf{7 1}$ & $\mathbf{1 2 0}$ \\
\hline
\end{tabular}

4) Respondent's knowledge on PPA

The research wanted to know the number of respondents who has knowledge in public procurement act. From the data collected, shows that $81.7 \% \quad(n=98)$ claimed to have knowledge on the procurement regulation, 5\% $(n=6)$ respondents admitted to lack the knowledge of public procurement act, and $13.3 \%(n=16)$ responded being unsure on understanding PPA.

Table VII shows respondents distribution of their understanding of public procurement act (PPA 2011).

Table VII. Respondent's Knowledge on PPA

\begin{tabular}{|c|c|c|c|c|}
\hline \multicolumn{2}{|c|}{} & \multicolumn{2}{|c|}{ Sector } & \multirow{2}{*}{ Total } \\
\cline { 3 - 5 } \multicolumn{2}{|c|}{} & Private Entity & Public Entity & \\
\hline \multirow{3}{*}{ Valid } & Yes & 37 & 62 & 99 \\
\cline { 2 - 5 } & No & 5 & 0 & 5 \\
\cline { 2 - 5 } & Not sure & 7 & 9 & 16 \\
\hline \multicolumn{2}{|c|}{ Total } & 49 & 71 & 120 \\
\hline
\end{tabular}

\section{Statistical data analysis}

\section{Results on Impact of regulations on the Performance of a public supply chain.}

The questions were structured in a way that will be able to capture important information that will help researcher to draw conclusion on the influences of variables on the research question so that inferential conclusion can be drawn.

Research questions 10, 11, 14 and 27 where aimed to capture information about the existence of innovation in the supply chain being the element that contributes to the performance. Research question 12,13,17,19 and 22 was aimed to capture information on the efficiency in both sectors for easier comparisons of the public sector supply chain. Responsiveness impact on the supply chain was measured by questions 15, 16, 18, 20 and 22.

Researcher approaches for statistical analysis was descriptive statistics, where the application of t-test, regression analysis and correlation were done to help to answer the research questions.

\section{1) Descriptive Statistics}

Table VIII below shows descriptive statistics for the most important variables that have intended to capture the relation of regulation and supply chain performance. Also descriptive statistics for the main variables was aimed to test normal distribution of the items as shown in the table VIII below. The variables seem to be distributed normally.

Table VIII. Descriptive Statistics For Key Variables

\begin{tabular}{|l|l|l|l|}
\hline \multicolumn{1}{|c|}{ Variables Questions } & N & Mean & Std. \\
\hline $\begin{array}{l}\text { Public Procurement Official has narrow } \\
\text { perspective in the supply chain operations as } \\
\text { compared to the private supply chain officials }\end{array}$ & 120 & 3.53 & 1.582 \\
\hline $\begin{array}{l}\text { Public Procurement Act and Regulation allows } \\
\text { In1vation }\end{array}$ & 120 & 3.96 & 1.662 \\
\hline $\begin{array}{l}\text { Public Procurement Act (PPA) and its Regulation, } \\
\text { emphasis enforcement of law and compliance thus } \\
\text { sacrificing value for money }\end{array}$ & 120 & 3.86 & 1.600 \\
\hline $\begin{array}{l}\text { There positive relationship between Procurement } \\
\text { Regulations and Procurement performance. }\end{array}$ & 120 & 4.38 & 1.438 \\
\hline $\begin{array}{l}\text { PPA2011 emphasis more on the prevention of } \\
\text { misappropriation of public, and not performance }\end{array}$ & 120 & 4.29 & 1.475 \\
\hline $\begin{array}{l}\text { Procurement Laws and Regulations goes through } \\
\text { a lot of amendments thus creates confusions for }\end{array}$ & 120 & 4.18 & 1.388 \\
\hline $\begin{array}{l}\text { Procuring from a government Agency, increases } \\
\text { responsiveness and cost efficiency in public SC. }\end{array}$ & 120 & 3.87 & 1.555 \\
\hline $\begin{array}{l}\text { Agencies like GPSA and TEMESA have capacities } \\
\text { in terms of human resources, Financial, and ICT } \\
\text { to provide competitive service to public entities. }\end{array}$ & 120 & 2.88 & 1.676 \\
\hline $\begin{array}{l}\text { Procurement is used as transitional and routine } \\
\text { activities in the organization: }\end{array}$ & 120 & 3.84 & 1.582 \\
\hline $\begin{array}{l}\text { Public Procurement Act (PPA) should give the } \\
\text { flexibility for Public official }\end{array}$ & 120 & 4.78 & 1.286 \\
\hline $\begin{array}{l}\text { The current Acts, has some shortfalls; that a } \\
\text { necessary further amendments }\end{array}$ & 120 & 4.80 & .958 \\
\hline $\begin{array}{l}\text { Suppliers and public at large have limited capacity } \\
\text { to understand the regulation requirement }\end{array}$ & 120 & 4.20 & 1.459 \\
\hline & 120 & & \\
\hline
\end{tabular}




\begin{tabular}{|c|c|c|c|c|c|c|c|c|c|}
\hline \multicolumn{2}{|c|}{ Table IX. Impact of Regulation on Innovation in The Public's Supply Chain } \\
\hline \\
\hline
\end{tabular}

1) Impact of regulation on innovation in the public's Supply chain

From regression analysis

$$
Y=15.980+0.978 \times 1
$$

a. Dependent Variable: Total Innovation

b. Predictors: (Constant), 4. Are you working with private or public procuring entity?

The regression analysis showed positive relationship between innovation and other factors keeping constant sector

Testing of Hypothesis

$\mathrm{Ho}=$ PPA2011 has no impact on public supply chain performance in terms of innovation

H1= PPA2011 has impact on public supply chain performance in terms of innovation

- The significant level was sated at $\alpha=0.05$ so for two sided test $\alpha=0.025$, at $95 \%$ confidence Interval

- From the Table of student's $t$ distribution, (Newbold et al, 2013) we found that the cutoff points are at -tn-1, $\alpha / 2=-1.96$ and $\mathrm{tn}-1, \alpha / 2=+1.96$, the rejection region is (-inf, -1.96) or (1.96, inf). Reject H0 if the value of tstatistic falls within the rejection region.

- From the Table VII, t-statistic of the total Innovation is -1.52 , which locates outside the rejection region.

As indicated in table VII, above the study shows that the independent samples do not show statistically significant difference between sectors, since the t-stat does not fall into the rejection region.

This result fails to reject the null hypothesis $\mathrm{HO}$. Thus author conclusion is that PPA2011 has no impact on public supply chain performance in terms of innovation.

The score is numerically higher value in public sector, (Public entity, $\mathrm{N}=71$ ), that PPA 2011, and its Regulation couldn't be associated with the inefficiency of the performance of the public supply chain with Mean=16.96 ( $\mathrm{SD}=3.082) . \quad$ By comparison, non-regulated supply chain (Private, $\mathrm{N}=49$ ) was less associated with regulation impact on innovation in private sector, having numerically smaller, Mean=15.98 $(\mathrm{SD}=3.955)$.
These results go against the findings of different researchers in the field of public supply chain management like [31] and[34]. The contradictory findings from this study might have been due to the reason that, respondents failed to understand the meaning of innovation when it comes to the procurement process as opposed to the technological innovation which is well known.

Also another factor might have been the lack of the room for innovation in public procurement where many respondents are coming from, and this has caused innovation to be something strange before public supply chain practitioners in Tanzania.

Innovation is limited by lack of support from PPA2011, also fear among public officials in case innovation will not work well, they will be in a risk to be punished by law because of public resources are considered to be wasted.

Pegnato [28] argued that compliance means the minimization of the decisions making risk in the public procurement process by imposing highly regulated processes Assessment of the management performance is based on the level of compliance with the prescribed processes, and hence minimizing the chance to come up with new idea. A highly regulated procurement system is designed to minimize the risk that might occur due to the discretion of the practitioners in a highly risk decision making.

The penalty of the regulations as come up with the lack of flexibility in the management of the agency needs effectiveness and efficiency. The main functions of the mainly codification processes is to protect the government from the political scandals.

Schapper [29] affirmed that regulation in public procurement as being fueled by the political fight for the public confidence that is built on the pillars of transparency, equity and fair dealings. Procurement alike to other government function is regarded as the processing of the administrative process and implementation of the policy through highly regulated system, thus limiting a chance for sustainable innovative ideas. 


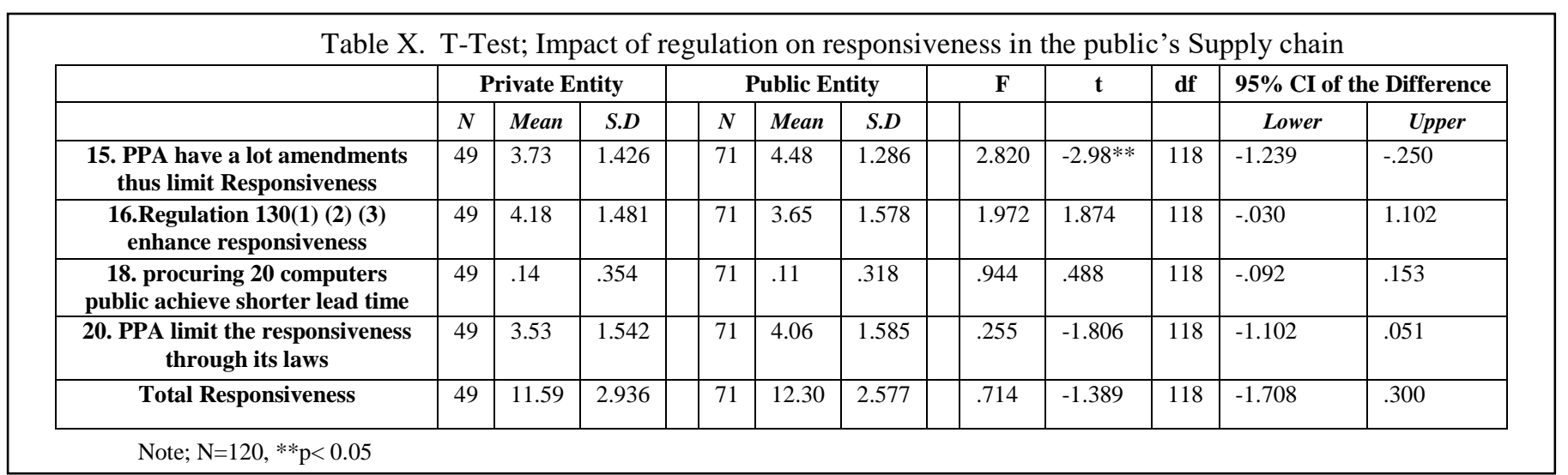

2) Impact of regulation on responsiveness in the public's Supply chain

From regression analysis

$$
Y=11.592+0.704 X 1
$$

a. Dependent Variable: Total Responsiveness

b. Predictors: (Constant), 4. Are you working with private or public procuring entity?

The regression analysis showed positive relationship between responsiveness and other factors keeping constant sector.

Testing of Hypothesis

$\mathrm{Ho}=\mathrm{PPA} 2011$ has no impact on public supply chain performance in terms of responsiveness

H1= PPA2011 has impact on public supply chain performance in terms of responsiveness

- The significant level was sated at $\alpha=0.05$ so for two sided test $\alpha=0.025$, at $95 \%$ confidence Interval

- From the Table of student's t distribution, (Newbold et al, 2013) we found that the cutoff points are at -tn-1, $\alpha / 2=-1.96$ and $\operatorname{tn}-1, \alpha / 2=+1.96$, the rejection region is (-inf, -1.96) or (1.96, inf).

- Reject HO if the value of t-statistic falls within the rejection region.

As indicated in Table $X$ the study shows that the independent samples does not show statistically significance difference between sectors to influence responsiveness, since the $\mathrm{t}$-statistics did not fall in the rejection area.

This result fail to reject null hypothesis that PPA2011 has no impact on public supply chain performance in terms of responsiveness.

Comparing score numerically a higher value, (Public entity, $\mathrm{N}=71$ ), show that PPA 2011, and its Regulation couldn't be associated with the inefficiency of the performance of the public supply chain with Mean=16.96 ( $\mathrm{SD}=3.082)$. By comparison, non-regulated supply chain (Private, $\mathrm{N}=49$ ) was less associated with regulation impact on innovation in private sector, having numerically smaller, Mean=15.98 $(\mathrm{SD}=3.955)$.
On the individual variable level, Qn. 15 explained the relationship that the regulation has in a contrast way. This might be caused by more experience of public sector employees on the public procurement laws and regulations. Table below shows that the PPA 2011 and its regulations is associated with limiting responsiveness in the public organizations, with number of responses $(\mathrm{N}=71)$, was associated with numerically Mean $=4.48 \quad(\mathrm{SD}=1.286)$. By comparing private sector $(\mathrm{N}=49)$, was associated with numerically Mean=3.73(SD=1.426).

The results indicated that excessive amendments to the law and regulations has effect to measure the performance of public supply chain with significant difference at $95 \%$ confidence level.

Question 20 which explicitly asked about the PPA limit the responsiveness through its laws, the public sector scored higher mean indicating that, laws have impacts in the responsiveness of the public supply chain but the difference in mean was not significant to be justified over the counterparty private sector.

The overall results of responsiveness after summation of all responsiveness variables go against the findings of many researchers like Mohr et al [30] and Herer et al [31].The author presumes that; this surprising result might have been caused by the fact that more respondents were from the public sector. Public sector supply chain in Tanzania does not emphasize on the responsiveness rather the efforts are put on the cost effectiveness. This can be well justified by the PPA2011, where in all sections, there is no part that has explicitly emphasized on the responsiveness, and no any penalty have been identified to be imposed to either the public officials, nor to the supplier in the case delays or lack of quick responses. This has been put in the hands of public officials to negotiate with suppliers on the required level of responsiveness, and hence has created corruption practices and delays in the provision of the social services.

Many kinds of literature have identified how crucial responsiveness is important in a successful supply chain. Researchers have identified information sharing to be very important strategic decision, and nowadays private companies compete each other through how well they manage information. Many companies have been invested a lot in information sharing for the entire supply chain from material producer to final consumer. The timely flows of information 
help in coordination of supply chain activities and hence increase responsiveness.

Mohr et al [30] aasserted that; a direct and frequently communication between in part to another creates a communication quality. The quality communication results higher satisfaction and hence stimulates higher performance between parties in communication.

Herer at al [31] Argued that, the amount of time provided to communicate through documentation and laid procedures, affect the performance of the supply chain. Then he concluded that sufficient lead time promotes compliance, and ultimately the performance of public supply chain. In Tanzania, it took from 7 days to 45 days to finish tendering processes. The shortfalls fall on the many processes and unnecessary documentation that can delays service provisions.

3) Impact of regulation on efficiency in the public's Supply chain

From regression analysis

$$
Y=20-1.972 X 1
$$

a. Dependent Variable: Total Efficiency

b. Predictors: (Constant), 4. Are you working with private or public procuring entity?

The regression analysis showed negative relationship between efficiency and other factors keeping constant sector
- Reject H0 if the value of t-statistic falls within the rejection region.

From the Table XII, t-statistic of the total Innovation is 3.238, which locates inside the rejection region.

As indicated in Table XII, the study shows that the independent samples shows statistically significance difference between sectors to influence efficiency since the t-statistics falls in the rejection area.

\section{This result reject null hypothesis that PPA 2011 has no impact on public supply chain performance in terms of efficiency.}

PPA 2001, and its Regulation (Public entity, N=71), was associated with the inefficiency of the performance of the public supply chain, in terms of efficiency with Mean $=18.03$ ( $\mathrm{SD}=3.162)$.By comparison, non-regulated supply chain (Private, N=49) scored numerically higher Mean=20 $(\mathrm{SD}=3.44)$. Thus the study reveals that PPA 2011 has impact to the performance of the public supply chain in terms of efficiency.

The main weakness in Facilities and services sourcing is lack of due diligence in assessing the trade-off between cost and benefit of sourcing from outside; compared to cost for additional resources to perform the activities internally, or to build government owned facilities[32].

\begin{tabular}{|c|c|c|c|c|c|c|c|c|c|c|c|}
\hline \multirow[t]{2}{*}{ Variables } & \multicolumn{3}{|c|}{ Private Entity } & \multicolumn{3}{|c|}{ Public Entity } & \multirow[t]{2}{*}{$\mathbf{F}$} & \multirow[t]{2}{*}{$\mathbf{t}$} & \multirow[t]{2}{*}{ df } & \multicolumn{2}{|c|}{ 95\% C I of the Difference } \\
\hline & $N$ & Mean & $S D$ & $N$ & Mean & $S D$ & & & & Lower & Upper \\
\hline $\begin{array}{l}\text { 13. There positive relationship between } \\
\text { PPA and Efficiency }\end{array}$ & 49 & 4.59 & 1.368 & 71 & 4.23 & 1.475 & 1.397 & 1.377 & 118 & -.160 & .893 \\
\hline $\begin{array}{l}\text { 17. For a given task Public will achieve } \\
\text { efficiency }\end{array}$ & 49 & 3.33 & 1.853 & 71 & 2.63 & 1.514 & 14.078 & $2.242 *$ & 118 & .082 & 1.303 \\
\hline 22. (PPA 2011)needs amendments & 49 & 4.69 & 1.084 & 71 & 4.87 & .861 & 3.256 & -1.008 & 118 & -.532 & .173 \\
\hline Total Efficiency & 49 & 20.00 & 3.440 & 71 & 18.03 & 3.162 & 1.709 & $3.238^{*}$ & 118 & .766 & 3.177 \\
\hline Note $; \mathrm{N}=120, * * \mathrm{p}<0.05$ & & & & & & & & & & & \\
\hline
\end{tabular}

\section{Testing of Hypothesis}

$\mathrm{Ho}=$ PPA2011 has no impact on public supply chain performance in terms of efficiency

$\mathrm{H} 1=$ PPA2011 has impact on public supply chain performance in terms of efficiency.

- The significant level was sated at $\alpha=0.05$ so for two sided test $\alpha=0.025$, at $95 \%$ confidence Interval

- From the Table of student's $t$ distribution (Newbold et al, 2013), we found that the cutoff points are at -tn-1, $\alpha / 2=-1.96$ and $\operatorname{tn}-1, \alpha / 2=+1.96$, the rejection region is (-inf, -1.96) or (1.96, inf).
The other problem of sourcing comes from the lack of capacity for public official on the negotiation strategies so that they can come up with good deals over the service providers.

Also there is limitation in selecting and maintenance sources of supplies, innovation and cost control issue since suppliers and public entities have transactional relationship.

Regulations 130(1) affect pricing and hence effectiveness (cost), because requires procuring entity to procure from government agencies using framework contracts. Since agencies have no capacity, usual they subcontract or procure from other private supplies and resell to government entities and hence the price is increased. The law creates unnecessary stage of middle man (agencies) and hence efficiency cannot be attained (due to cost increase). 


\section{CONCLUSION AND RECOMMENDATIONS}

\section{A. Introduction}

This Section will draw conclusion on the finding that was self-explain in analysis conducted in Section four. In line with the conclusion about this study, the recommendation will be offered to the key stakeholder whom in one way or another thesis results can be utilized to solve some supply chain related issues in the public supply chain. The researcher finally suggested some future studies that can be propagated from this thesis as a starting point.

\section{B. Conclusion}

The study was aimed to explain the impacts that laws and regulations can impart on the public supply chain. The results showed that the regulation has significant impact on the performance of public supply chain on the cost item (efficiency).

The Third hypothesis that PPA 2011 has no impact on the supply chain performance in terms of efficiency was rejected, and alternative hypothesis adopted to affirm that there is negative impact of the regulations over cost, and hence detriment performance in public sector.

The research findings compliment different researcher on public procurement like Pyke et al [33], Alvarado [34], and Boyne et al [35].

Surprisingly, the study was not able to reject the first and the second null hypothesis, which state that, H1o= PPA2011 has no impact on public supply chain performance in terms of innovation and $\mathrm{H} 2 \mathrm{o}=$ PPA2011 has no impact on public supply chain performance in terms of responsiveness. This is possibly cause by the failure for private sector to understand some PPA2011 sections that required respondents to give their ratings on the scale of 1-6 that were presented by strongly disagree, disagree, rather disagree, rather agree, agree and strongly agree. Moreover failure to reject this hypothesis goes against many researchers on this area.

Diller [36], asserted that public procurement is famous know being tactical, and many public organizations consider to be a clerical work that seems not to require attention in terms of resources. He further noted that the public entities have less effort to make supply chain in the public entities to be a priority strategic area.

On the other hand I agree with the study findings as recently, the supply chain importance in strategically contribution to achieve corporate objectives has been acknowledged not only the private entities but also the public entities. This signifies that supply chain management has been an area where have been given less attention. Efficiency becomes critical area where a competitive supply chain has been rated.

This observation was supported by individual analysis of questions that were asked in the questionnaire. The study identified that now day the public entities are putting more effort to harness the strategic benefit of SC by training their manpower, where by public sectors emerged to have more respondents who hold master's degree compared to the private sectors where majority hold first bachelor degree.

On other hand; innovation and responsiveness, the study did not conclude of these factors, as the researcher found to have limited evidence to prove that the PPA2011 doesn't have impact.

This conflicting observation concludes that supply chain management in the public sector is challenging area that creates confusion and ambiguity not only to the policy makers but also the practitioner. From the research's drawn conclusion, recommendations were.

\section{Recommendation}

\section{1) For Policy Markers (Government)}

The meaning and essence of having PPA2011 and regulation is appreciated by every individual in both public and private sector, but the implementation of the laws as created challenges that are limiting procurement officials to use modern ways that can bring value to the organization.

Government should use experts from the operations in the supply chain to give feedback on the way they think supply chain can bring value, rather than relying on the politician in the parliament who makes excessive amendments of laws to respond to current hit issue in the area of public spending. This approach of using politicians has further increase the cost of implementation of the system as well as the frequency of training for the procurement staff due to the over changing of the regulations.

Also since the last amendment of the law was PPA2011, It is obvious that there are new issues that need attention due to the changes in the economic and social environment that can detriment affect the performance of the supply chain. Many respondents commented that is the time for the government to overhaul the all system of procurement by removing areas that have been causing inefficiency.

Procurement regulations seems to be more effective in the lack of expertise or limited procurement skills by procurement practitioners, and where the government has high degree of corruption in the procurement system, now this is challenge for the government to find the policy and ways on how to enforce ethics in the public supply chain, rather using laws to base on one side of corruption prevention, instead of using supply chain as a strategic tool that can be used to bring value for the public spending.

Generally, regulated processes are procedurally costly, and also bring challenges in the management of the simple procurement since it slowly adapting to the changes that should be linked to the complexity and ever changing sophisticated supply chain. The other consequences are the erosion of the skills and personal developmental in the decisions making, therefore undermining their professionalisms.

\section{2) For Researcher}

The research main objective was to find the impact of the regulation can impose in the public supply chain performance. 
The results had brought mixtures of conclusion in terms of key performance terms. The study affirmed that, the PPA2011 has negative impact on efficiency (Cost) and also the result failed to get enough evidence to prove the claimed results that PPA2011 has a positive impact in terms of the responsiveness and innovation.

Future researcher can repeat the same study in Tanzania after the amendment of new PPA, or same study can be conducted in other countries to find out the impact of laws and regulations on public supply chain. Also Future study can be carried only on one variable, which is efficiency, effectiveness or innovation so that to establish the relation the law enforcement has with public supply chain performance.

\section{References}

[1] Mamiro, R. G. (2010). Value for money, the limping pillar in public procurement-Experience from tanzania'. 4th International Public Procurement Conference,

[2] Nkinga, E. N. (2003). Public procurement reform: The tanzanian experience. Joint WTO-World Bank Regional Workshop on Procurement Reforms and Transparency in Public Procurement for Anglophone African Countries, 14-17.

[3] James, O. (2000). Regulation inside government: Public interest justifications and regulatory failures. Public Administration, 78(2), 327343.

[4] Matsushita, M., Schoenbaum, T. J., Mavroidis, P. C., \& Hahn, M (2015). The world trade organization: Law, practice, and policy Oxford University Press.

[5] Meindl, P., \& Chopra, S. (2001). Supply chain management: Strategy, planning, and operation, 5/e Pearson Education India.

[6] Ambe, I. M., \& Badenhorst-Weiss, J. A. (2012a). Procurement challenges in the south african public sector. Journal of Transport and Supply Chain Management, 6(1), 242-261.

[7] Christopher, M. (2005). Logistics and supply chain management: Creating value-adding networks Pearson education.

[8] Muriel, A., \& Simchi-Levi, D. (2003). Supply chain design and planning-applications of optimization techniques for strategic and tactical models. Handbooks in Operations Research and Managemen Science, 11, 15-93.

[9] Ambe, I. M., \& Badenhorst-Weiss, J. A. (2012b). Supply chain management challenges in the south african public sector. African Journal of Business Management, 6(44), 11003.

[10] Migiro, S., \& Ambe, I. (2008). Evaluation of the implementation of public sector supply chain management and challenges: A case study of the central district municipality, north west province, south africa. African Journal of Business Management, 2(12), 230.

[11] Huang, Y., Huang, G. Q., \& Newman, S. T. (2011). Coordinating pricing and inventory decisions in a multi-level supply chain: A game-theoretic approach. Transportation Research Part E: Logistics and Transportation Review, 47(2), 115-129.

[12] McGuinness, K., \& Bauld, S. (2004). Is negotiation underutilized in public procurement? Summit: Canada's Magazine on Public Sector Purchasing, 7(3), 28.

[13] Anderson, L. W., Krathwohl, D. R., \& Bloom, B. S. (2001). A taxonomy for learning, teaching, and assessing: A revision of bloom's taxonomy of educational objectives Allyn \& Bacon.

[14] Guston, D. H. (1996). Principal-agent theory and the structure of science policy. Science and Public Policy, 23(4), 229-240.

[15] Barrow, M. (1996). Public services and the theory of regulation. Policy \& Politics, 24(3), 263-276.

[16] Alchian, A. A., \& Demsetz, H. (1972). Production, information costs, Migiro, S., \& Ambe, I. (2008). Evaluation of the implementation of public sector supply chain management and challenges: A case study of the central district municipality, north west province, south africa. African Journal of Business Management, 2(12), 230.

[17] Fama, E. F., \& Jensen, M. C. (1983). Separation of ownership and control. The Journal of Law and Economics, 26(2), 301-325.

[18] Bledow, R., Frese, M., Anderson, N., Erez, M., \& Farr, J. (2009). A dialectic perspective on innovation: Conflicting demands, multiple pathways, and ambidexterity. Industrial and Organizational Psychology, 2(3), 305-337.

[19] Benner, M. J., \& Tushman, M. L. (2003). Exploitation, exploration, and process management: The productivity dilemma revisited. Academy of Management Review, 28(2), 238-256.

[20] McCubbrey, A. L., Nelson, J. D., Stolberg, V. R., Blakely, P. K., McCloskey, L., Janssen, W. J., . . Curtis, J. L. (2016). MicroRNA-34a negatively regulates efferocytosis by tissue macrophages in part via SIRT1. Journal of Immunology (Baltimore, Md.: 1950), 196(3), 13661375. doi:10.4049/jimmunol.1401838 [doi]

[21] Mason, S. J., Ribera, P. M., Farris, J. A., \& Kirk, R. G. (2003). Integrating the warehousing and transportation functions of the supply chain. Transportation Research Part E: Logistics and Transportation Review, 39(2), 141-159.

[22] Wong, C. W., Wong, C. Y., \& Boon-itt, S. (2013). The combined effects of internal and external supply chain integration on product innovation. International Journal of Production Economics, 146(2), 566-574

[23] Tadelis, S. (2012). Public procurement design: Lessons from the private sector. International Journal of Industrial Organization, 30(3), 297-302.

[24] Chopra, S. (2016). Supply chain management: Strategy, planning, and operation, 6/e Pearson Education India.

[25] Newbold, Paul, William Carlson, and Betty Thorne. Statistics for business and economics. Pearson, 2013.

[26] Lee, H. L., \& Billington, C. (1992). Managing supply chain inventory: Pitfalls and opportunities. Sloan Management Review, 33(3), 65.

[27] Groves, T., \& Loeb, M. (1979). Incentives in a divisionalized firm. Management Science, 25(3), 221-230.

[28] Pegnato, J. A. (2003). Assessing federal procurement reform: Has the procurement pendulum stopped swinging? Journal of Public Procurement, 3(2), 145.

[29] Schapper, P. R., Malta, J. N. V., \& Gilbert, D. L. (2006). An analytical framework for the management and reform of public procurement Journal of Public Procurement, 6(1/2), 1.

[30] Mohr, J. J., \& Sohi, R. S. (1996). Communication flows in distribution channels: Impact on assessments of communication quality and satisfaction. Journal of Retailing, 71(4), 393-415.

[31] Herer, Y. T., \& Levy, R. (1997). The metered inventory routing problem, an integrative heuristic algorithm. International Journal of Production Economics, 51(1-2), 69-81.

[32] Seshadri, S. (2005). Sourcing strategy Springer.

[33] Pyke, D. F., \& Cohen, M. A. (1994). Multiproduct integrated production - distribution systems. European Journal of Operational Research, 74(1), 18-49.

[34] Alvarado, U. Y., \& Kotzab, H. (2001). Supply chain management: The integration of logistics in marketing. Industrial Marketing Management, 30(2), 183-198.

[35] Boyne, G. A. (2002), Public and Private Management: What's the Difference?. Journal of Management Studies, 39: 97-122. doi:10.1111/1467-6486.00284

[36] Diller, M. (2000). The revolution in welfare administration: Rules, discretion, and entrepreneurial government. NYUL Rev., 75, 1121 